\title{
Mapping The Drought Area Through Landsat 8 OLI/TIRS With LST Model SWA-S Method in Banyuwangi Regency
}

\author{
Yesi Anita Sari ${ }^{1}$, I Putu Sriartha ${ }^{1}$, A Sediyo Adi Nugraha ${ }^{1}$ \\ Yesianita0199@gmail.com, adi.nugraha@undiksha.ac.id ${ }^{3}$ \\ ${ }^{1}$ Universitas Pendidikan Ganesha, Indonesia
}

\begin{abstract}
Drought-affected areas are critical to disaster reduction. The objective of the research is to discover how the drought spread with Landsat 8 OLI images, in particular by identifying the Land Surface Temperature (LST). The LST method involves determining vegetation emissions, known as the Normalized Dryness Vegetation Index (NDVI). The results showed that the drought location based on differences in land surface temperatures was in coastal areas and residential areas such as Banyuwangi and Muncar with 321-329 degrees Kelvin. Then in areas with Hills, topography shows the potential for drought with an area temperature of 308-321 degrees Kelvin. Furthermore, the field survey of temperature distribution accuracy-test revealed $90 \%$. Based on these results, it can be concluded that LST can be used to identify drought with Landsat 8 OLI image
\end{abstract}

Keywords: Drought, Landsat 8, LST, NDVI

\section{Introduction}

Drought is a phenomenon that cannot be known when it begins and ends[1]. In addition, drought takes time to be felt for the community[2]. So it requires drought identification to be able to be mitigation against areas that have a level of vulnerability to the phenomenon of drought.

Remote sensing today has many developments, particularly in drought identification.Several studies, such as those conducted by Parwati and Suwarsono [3], used Citra Modis data as primary data and used secondary data, namely landuse and landcover from Landsat ETM+ 2002/2003 data, with the TVDI method using two parameters, namely EVI and LST. The study uses TVDI analysis combined with land use data from Landsat 7 ETM+ $2002 / 2003$ with the results of sensitivity of agricultural areas to drought compared to scrub areas. In addition, another study conducted by Hadi, Danoedoro, and Sudaryatno [4] examined the TIRS channel's accuracy on the Aster Image, which is also the data used in this study. The secondary data used are rainfall data, air temperature data and SRTM data for part of the GunungKidul Region, and using TVDI as the method but using a different vegetation index parameter, namely NDVI with surface temperature (LST). The analysis used is the result of the drought area from the TVDI Index and the Thornwaite-Mather method, which identifies different results due to very minimal rainfall conditions at the study site. In addition to these two studies, Adi and Sudaryatno [5] also used remote sensing to assess the distribution of 
drought and test the accuracy of the SAVI vegetation index. The data used in this study was Landsat 8 Oli/Tirs imagery with TVDI using SAVI parameters, and The LST analysis used is the RMS error value of SAVI, which was tested with conditions in the field and the results of the TVDI analysis of SAVI and LST.

One of the variables commonly used is Land Surface Temperature (LST). This method is seen as more efficient when compared to the acquisition of surface temperature directly on the ground [6]. In the results obtained by Nugraha[7], LST using SWA-S models obtained from the extraction of vegetation and water vapour indexes get a significant difference in results due to the impact of emissivity values. In this regard, with the difference in emissivity more evenly or methods with a comparison of soil surface temperature from different topographies in the area where the study is expected to get more accurate results. In this case, Remote Sensing Imagery is needed as a data provider. The image data used in this study is Landsat Image 8 OLI/TIRS. There have been no studies measuring the accuracy of imagery in identifying drought using the LST method with this model. It is necessary for areas with the potential to drought, and the chosen area is Banyuwangi because it is one of the ten areas experiencing drought in 2019[8]. In addition, Banyuwangi Regency also has rainfall data that can support this research in terms of validating drought identification data.

This study aims to measure the accuracy rate of Landsat Image 8 using LST to find out drought conditions, and it is expected that the results of this study can be a reference in terms of monitoring and mitigation of drought phenomena in Banyuwangi Regency.

\section{Methodology}

\subsection{Study Area}

Banyuwangi is one of the regencies in East Java that is located at coordinates $7^{\circ} 43^{\prime}-8^{\circ}$ 46' LS and $113^{\circ} 53^{\prime}-114^{\circ} 38^{\prime}$ BT (Figure 1). The southern part borders Situbondo Regency, the east is the Bali Strait, the south is the Indian Ocean, and the West is bordered by two districts, namely Jember and Bondowoso Regencies[9]. Banyuwangi's varied topography where the western and northern parts are mountainous areas, and in the south most of the area is lowlands, making the area's location and differences in land cover characteristics of the region that ultimately affect soil moisture.

\subsection{Land Surface Temperature}

Landsat $8 \mathrm{OLI} / \mathrm{TIRS}$ imagery is the data used in this study, obtained from the official USGS website: http://usgs.gov/. Processing Landsat image 8 OLI/ TIRS starts from preprocessing, such as radiometric correction, atmospheric correction, and cropping image of Banyuwangi Regency from Recording Landsat 8 OLI/ TIRS Image in September and cloud cropping to prevent distortion in extraction results. It further condenses the image into brightness temperature (BT) by the USGS method in which K1 and K2 constants Band 10 and Band 11, and as spectral emissions of bands 10 and 11 with equations (1) as follows:

$$
\mathrm{BT}=\mathrm{K}_{2} / \ln \left[\left(\mathrm{K}_{1} / \mathrm{L} \lambda\right)+1\right]
$$

After obtaining the brightness temperature is further extracted into the soil's surface temperature with a method developed by Sobrino et al. [7], which uses Fractional Vegetation Cover with water vapour in the equation (2). 
$\mathrm{LST}=T B_{10}+C_{1}\left(T B_{10}-T B_{11}\right)+C_{2}\left(T B_{10}-T B_{11}\right)^{2}+C_{0}+\left(C_{3}+C_{4} W\right)(1-m)+\left(C_{5}+\right.$ $\left.C_{6} W\right) \Delta m$

LST in the equation is Ground Surface Temperature; TB10 and TB11 are surface temperatures; while $\mathrm{C} 0$ - C6 is obtained from the table 1[10]-[13]; $\mathrm{W}$ is the water vapour value of MODIS data; $\mathrm{m}$ in the equation is the average of Land Surface Emissivity (LSE); while $\Delta \mathrm{m}$ is the difference between LSE from Bands 10 and 11.

Table1. Split-Windows Coefficient Value.

\begin{tabular}{cc}
\hline Constant & Value \\
\hline $\mathrm{C}_{0}$ & -0.268 \\
$\mathrm{C}_{1}$ & 1.378 \\
$\mathrm{C}_{2}$ & 0.183 \\
$\mathrm{C}_{3}$ & 54.300 \\
$\mathrm{C}_{4}$ & -2.238 \\
$\mathrm{C}_{5}$ & -129.200 \\
$\mathrm{C}_{6}$ & 16.400 \\
\hline
\end{tabular}

To get the LSE value that needs to be done, use the equation (3) with ES and EV to get from the emissivity value table in table 2 .

$$
\mathrm{LSE}=\varepsilon_{S} *(1-F V C)+\varepsilon_{V} * F V C
$$

Tabel 2. Emissivity Value

\begin{tabular}{crr}
\hline Emissivity & Band 10 & \multicolumn{1}{c}{ Band 11} \\
\hline$\varepsilon_{S}$ & 0.971 & 0.977 \\
$\varepsilon_{V}$ & 0.987 & 0.989 \\
\hline
\end{tabular}

Source: [10]-[13]

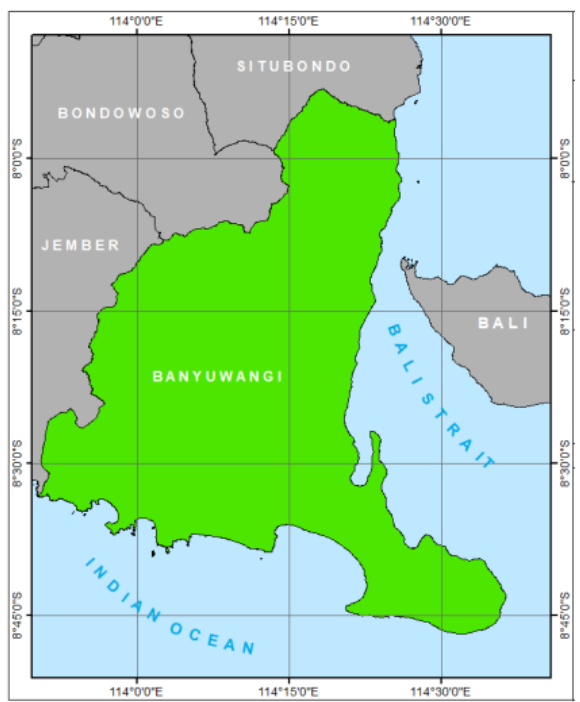

Fig. 1.Study Map Area 


\subsection{Normalized Dryness Vegetation Index (NDVI)}

The vegetation index is produced from equation (4), which uses Band 5, an Infrared channel, and band 4, a red channel developed by Huete et al.[14].

$$
\text { NDVI }=\frac{\text { Band } 5-\text { Band } 4}{\text { Band } 5+\text { Band } 4}
$$

While determining FVC (fractional vegetation cover) is done using equations developed by Sobrino et al.[15], which can be seen in equation (5).

$$
\mathrm{FVC}=\frac{N D V I-N D V I_{\text {soil }}}{\mathrm{NDVI}_{\text {soil }}-\mathrm{NDVI}_{\text {soil }}}
$$

NDVI is the vegetation index, NDVIsoil is the NDVI soil value, while NDVIvegetation is the NDVI vegetation value of the research site.

\subsection{Field Survey}

Image processing results will be validated by performing field checks with instruments and calculated accuracy levels using the error matrix put forward by Congalton\& Green[16], [17].

\section{Result and Discussion}

The result of image processing using three classes of vegetation density is high, medium, and low. Furthermore, the data is validated, with a high-density reference will be vegetation with a high classification and lush (Figure 2), medium density in the form of field vegetation and shrubs (Figure 3a), while low density in the form of fields/land without vegetation (Figure $3 b)$.
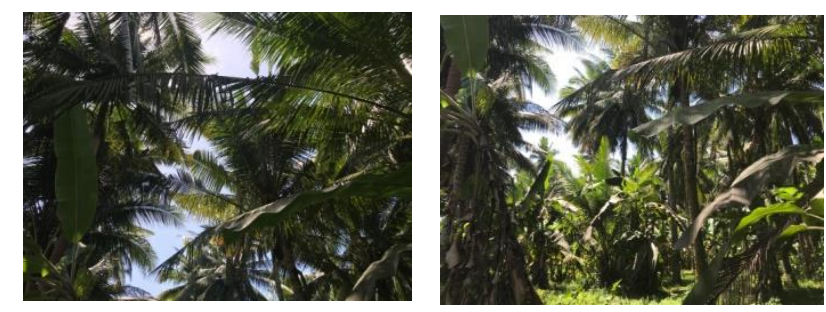

Fig. 1.Vegetation with High Density

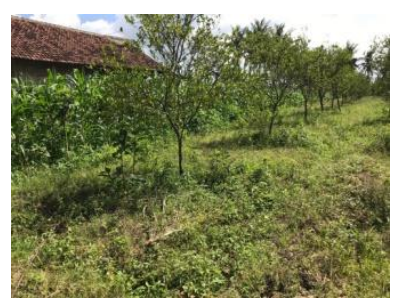

(a)

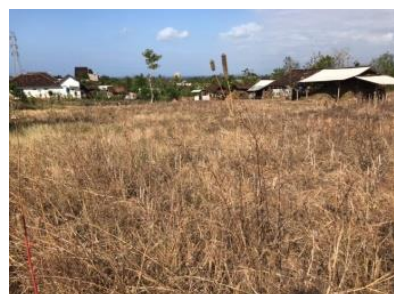

(b)

Fig.2.(a) Vegetation with Medium Density and (b) Vegetation With Low Density 
Vegetation density results reflect field conditions that measurements perform for accuracy tests using matrix tables. The sample taken is 50 samples on NDVI and drought identification with LST, such as Table 3 and Table 4. The results showed that drought identification with LST provided a high accuracy of $90 \%$. In comparison, the appearance of vegetation shows an accuracy of $88 \%$. This high accuracy is influenced by the time of measurements done in dry months so that conditions in the field show similarities with processing results. These results have similarities to Nugraha[18]-[20], which uses LST for drought identification. NDVI has a lower accuracy due to changes in vegetation appearance in dry months.High droughts are dominated by dryland farming (Figures 4). The results make the drought index into LST using the SWA-S model in Landsat Image 8 to identify droughts with high accuracy.

Table 3.Error Matrix of NDVI

\begin{tabular}{cccccc}
\hline \hline NDVI & High Density & $\begin{array}{c}\text { Medium } \\
\text { Density }\end{array}$ & $\begin{array}{c}\text { Low } \\
\text { Density }\end{array}$ & $\begin{array}{c}\text { Total } \\
\text { Rows }\end{array}$ & $\begin{array}{c}\text { Producer } \\
\text { Accuracy (\%) }\end{array}$ \\
\hline $\begin{array}{c}\text { High Density } \\
\text { Medium Density }\end{array}$ & 16 & 3 & 0 & 19 & 94 \\
Low Density & 1 & 17 & 1 & 19 & 85 \\
Total Colom & 17 & 1 & 11 & 12 & 92 \\
User Accuracy & 84 & 12 & 50 & \\
$(\%)$ & 89 & 92 & & \\
\hline OverallAccuracy $=(16+17+11) / 50=88 \%$ & & & \\
Source: & 0 & &
\end{tabular}

Source: Data Processing, 2021

Table 4.Error Matrix of Drought

\begin{tabular}{cccccc}
\hline \hline LST & Droughht & $\begin{array}{c}\text { Medium } \\
\text { Drought }\end{array}$ & Wetness & $\begin{array}{c}\text { Total } \\
\text { Rows }\end{array}$ & $\begin{array}{c}\text { Producer } \\
\text { Accuracy (\%) }\end{array}$ \\
\hline $\begin{array}{c}\text { Drought } \\
\text { Medium Drought }\end{array}$ & 17 & 2 & 0 & 19 & 94 \\
Wetness & 0 & 17 & 1 & 19 & 85 \\
Total Colom & 18 & 1 & 11 & 12 & 92 \\
User Accuracy & 89 & 89 & 12 & 50 & \\
$(\%)$ & & 91 & & \\
\hline
\end{tabular}

OverallAccuracy $=(17+17+11) / 50=90 \%$

Source: Data Processing, 2021
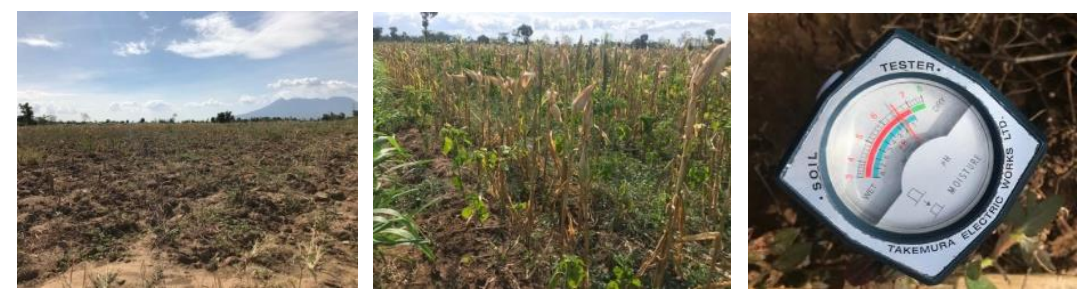

Fig. 4.Result of Drought with Soil Moisture Tester

Based on a map (Figure 5) of drought-prone areas from identification results using LST with SWA-S models, the areas with the highest drought levels are in theWongsorejo subdistrict that afflicts most agricultural land. Meanwhile, the level of drought is in the northern to the southern part of the region, with most settlements. In addition, low or wet drought is in areas with high vegetation such as highland areas in Glenmore, Kalibaru, Songgon and Licin and the southern Alas Purwo National Park area, which has conventional 
forest and mangrove areas.In addition, it is also known that there is a significant relationship between NDVI and LST of 0.95 with conditions if vegetation is high, then the temperature will be low and instead.

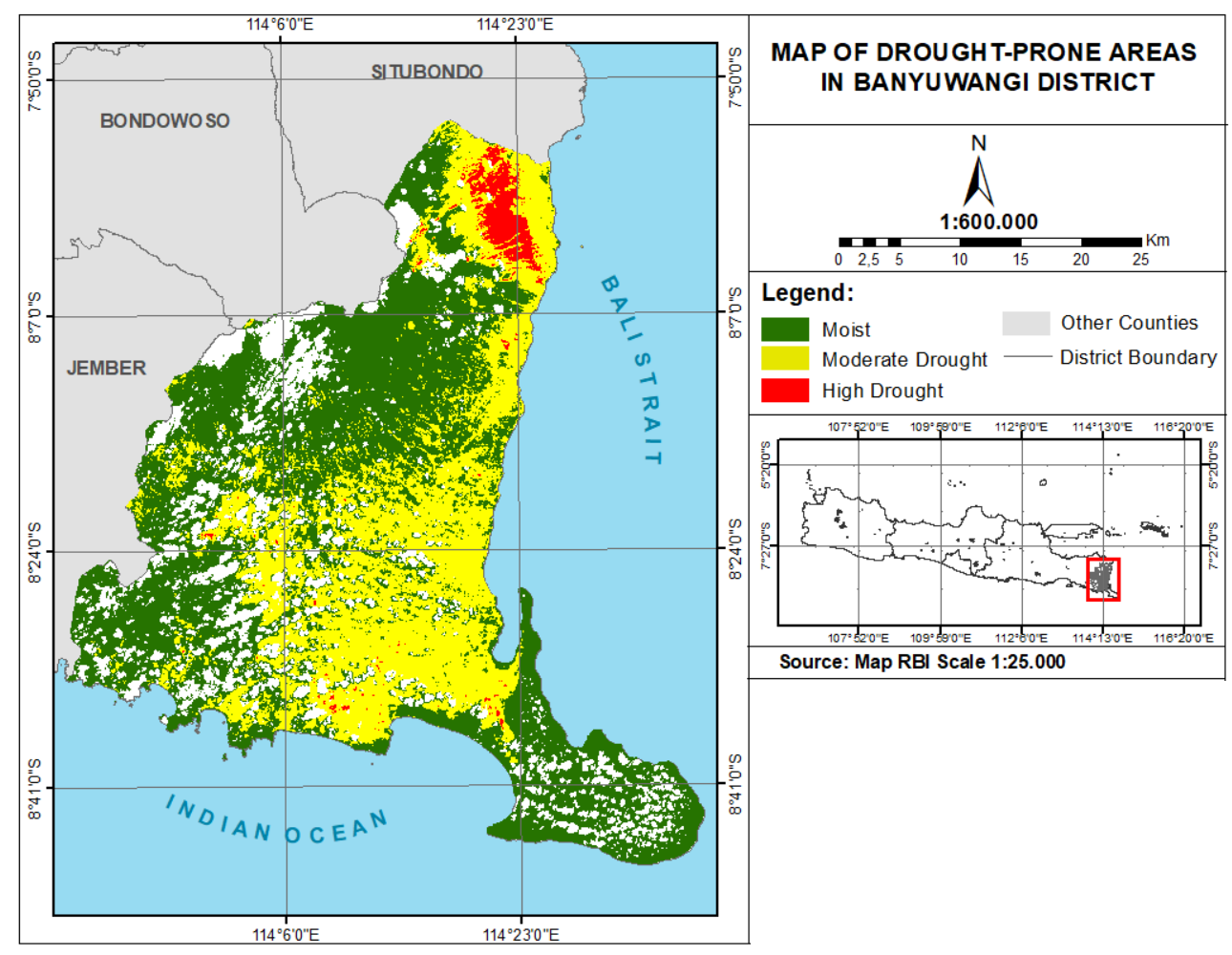

Fig. 5. Map of Drought of Banyuwangi Regency

\section{Conclusion}

The LST method using the SWA-S model has a relatively high accuracy rate of $90 \%$, in addition to the NDVI identification results in this study also have a high accuracy rate of $88 \%$. The spread of high drought areas is in Wongsorejo subdistrict on most agricultural land. Meanwhile, the drought is in settlements that start from the north to the south-central Banyuwangi regency. Low or wet drought is in the districts in the highlands, namely in the region, Glenmore, Pesanggraan, Kalibaru, Songgon, and Licin. The correlation relationship between NDVI and LST is relatively high.

\section{References}

[1] Indarto, S. Wahyuningsih, M. Pudjojono, H. Ahmad, and A. Yusron, "Studi Pendahuluan Tentang Penerapan Metode Ambang Bertingkat Untuk Analisis 
Kekeringan Hidrologi Pada 15 Das Di Wilayah Jawa Timur,” J. Agroteknologi, vol. 08, no. 02, 2014.

[2] R. Neritarani, "Identifikasi Dan Strategi Mitigasi Bencana Kekeringan Potensial Di Kabupaten Semarang," Fak. Sains dan Teknol., vol. 8, no. 1, 2019.

[3] Parwati and Suwarsono, "Model Indeks Tvdi (Temperature Vegetation Dryness Index) Untuk Mendeteksi Kekeringan Lahan Berdasarkan Data Modis-Terra," J. Penginderaan Jauh, vol. 5, pp. 35-44, 2008.

[4] A. P. Hadi, P. Danoedoro, and Sudaryatno, "Penentuan Tingkat Kekeringan Lahan Berbasis Lahan Berbasis Analisa Citra Aster dan Sistem Informasi Geografis," Maj. Geogr. Indones., vol. 26, no. 1, pp. 1-26, 2012.

[5] M. N. Adi and Sudaryatno, "Pemanfaatan Citra Landsat 8 untuk Penentuan Zonasi Kekeringan Pertanian di Sebagian Kabupaten Grobogan dengan Metode TVDI (Temperature Vegetation Dryness Index)," J. Bumi Indones., vol. 3, no. 4, 2014.

[6] A. S. A. Nugraha, "Effect of Emission Value for Land Surface Temperature on Landsat Image 7 ETM+," ICLSSE, 2020.

[7] A. S. A. Nugraha, "Pemanfaatan Metode Split-Windows Algorithm ( SWA ) pada Landsat 8 Menggunakan Data Uap Air MODIS Terra (The Application of SplitWindows Algorithm (SWA) Methods on Landsat 8 Using Modis Terra Water Vapor)," geomatika, vol. 25, no. 1, pp. 9-16, 2019.

[8] National Geographic Indonesia, "10 Daerah di Indonesia yang Mengalami Kekeringan Terpanjang," National Geographic Indonesia, 2019. [Online]. Available: https://www.google.com/amp/s/nationalgeographic.grid.id/amp/131944045/10-daerahdi-indonesia-yang-mengalami-kekeringan-terpanjang.

[9] Badan Pusat Statistik, "Kabupaten Banyuwangi dalam Angka 2020," Kabupaten Banyuwangi, 2021.

[10] J. A. Sobrino, J. El Kharraz, and Z. L. Li, "Surface temperature and water vapour retrieval from MODIS data," Int. J. Remote Sens., vol. 24, no. 24, pp. 5161-5182, 2003.

[11] J. A. Sobrino, Z. L. Li, M. P. Stoll, and F. Becker, "Multi-channel and multi-angle algorithms for estimating sea and land surface temperature with atsr data," Int. J. Remote Sens., vol. 17, no. 11, pp. 2089-2114, 1996.

[12] S. Zhao, Q. Qin, Y. Yang, Y. Xiong, and G. Qiu, "Comparison of two split-window methods for retrieving land surface temperature from MODIS data," J. Earth Syst. Sci., vol. 118, no. 4, pp. 345-353, 2009.

[13] D. Skokovic et al., "Calibration and Validation of land surface temperature for Landsat8- TIRS sensor TIRS LANDSAT-8 CHARACTERISTICS," L. Prod. Valid. Evol. ESA/ESRIN, p. 27, 2014.

[14] A. Huete, “A soil-adjusted vegetation index (SAVI)," Remote Sens. Environ., vol. 25, no. 3, pp. 295-309, 1988.

[15] J. A. Sobrino et al., "Land surface emissivity retrieval from different VNIR and TIR sensors," IEEE Trans. Geosci. Remote Sens., vol. 46, no. 2, pp. 316-327, 2008.

[16] R. G. Congalton, "A review of assessing the accuracy of classifications of remotely sensed data," Remote Sens. Environ., vol. 37, no. 1, pp. 35-46, 1991.

[17] R. . Congalton and K. Green, "Assessing The Accuracy of Remotely Sensed Data: Principles and Practices (2nd Edition)," in CRC Press, Taylor and Francis Group, 2008.

[18] A. S. A. Nugraha, T. Gunawan, and M. Kamal, "Comparison of Land Surface Temperature Derived from Landsat 7 ETM+ and Landsat 8 OLI/TIRS for Drought 
Monitoring," IOP Conf. Ser. Earth Environ. Sci., vol. 313, no. 1, pp. 0-10, 2019.

[19] A. S. A. Nugraha and D. M. Atmaja, "Split-windows algorithm (swa) methods using fractional vegetation cover (fvc) on landsat 8 oli/tirs," IOP Conf. Ser. Earth Environ. Sci., vol. 683, no. 1, 2021.

[20] A. S. A. Nugraha and D. M. Atmaja, "Pemanfaatan Citra Penginderan Jauh MultiTemporal Penggunaan Lahan Di Kabupaten Buleleng ( The Application of MultiTemporal Remote Sensing Images to Detect Urban Heat Island ( UHI ) for Land use Changes in Buleleng District )," Maj. Ilm. Globe, vol. 22, no. 2, pp. 71-82, 2020. 